EESTI NSV TEADUSTE AK'ADEEMIA TOIMETISED. 29. KंOIDẺ KEEMIA, 1980, NR. 4

ИЗВЕСТИЯ АКАДЕМИИ НАУК ЭСТОНСКОИ ССР. ТОМ 29 Химия. 1980, № 4

УДК $547.915+552.58+631.46$

И. КЛЕСМЕHT, К. УРОВ

\title{
РОЛЬ БАКТЕРИАЛЬНЫХ ЛИПИДОВ ПРИ ОБРАЗОВАНИИ ГЕОЛИПИДОВ И КЕРОГЕНОВ
}

Основное количество органического вещества на Земле находится в геосфере в виде концентрированных форм (фоссильные топлива) и рассеянного органического вещества. В настоящей работе рассматривается происхождение растворимой части органического вещества (геолипидов) и высокомолекулярного нерастворимого вещества топлив сапропелитового и липтобиолитового типа керогена. Основным биологическим источником для этих веществ служат липиды - для сапропелитов - липиды водных организмов, для липтобиолитов - наземных растений. Значительная часть органических веществ седиментов берет начало от бактериальных липидов. При седиментации косного органического вещества бактерии расходуют их нестабильные составляющие - белки и углеводы, при литификации в анаэробных условиях дальнейшее превращение протекает только при участии микроорганизмов [1, 2]. При разложении органических остатков бактерии синтезируют новые липиды, их селективное действие оставляет следы также на материале, избежавшем полной ассимиляции гетеротрофными микроорганизмами.

Рассмотрение даже целой биогеохимической обстановки не дает однозначного ответа на вопрос, какая часть геолипидов и керогенов имеет бактериальное происхождение. Наличие остатков фоссилизированных бактерий в каустобиолитах не служит достаточным основанием для того, чтобы считать первые главным источником вторых [3]. Более точные данные дает исследование химического строения фоссилизированного вещества на молекулярном уровне. Зная состав исходного биологического вещества, можно судить о характере процессов, протекающих при фоссилизации.

Господствует мнение, что в противоположность первичной биологической продукции в бактериальных кислотах не преобладают гомологи с четным числом атомов углерода, показатель отношения гомологов с четным и нечетным числом атомов углерода (коэффициент четности - КЧ) близок к единице [4]. Соответственно в бактериальных парафинах, которые часто являются продуктами декарбоксилирования кислот, преобладание «нечетных» гомологов невысокое (коэффициент нечетности $-\mathrm{KH} \simeq 1\left[{ }^{5}\right]$ ). Необходимо отметить, что в некоторых восстановленных седиментах преобладают парафины $\mathrm{C}_{15}$ и $\mathrm{C}_{17}$, присутствующие в больших количествах в водорослях и фотосинтезирующих бактериях [6] наряду с кислотами $\mathrm{C}_{16}$ и $\mathrm{C}_{18}\left[{ }^{7}\right]$. Среди бактериальных кислот и парафинов также много изомеров с разветвлением в углеродной цепи. Такие кислоты присутствуют уже в водорослях и они являются вторичными. Бактерии активно трансформируют

1 ENSV TA Toimetised. K 41980 
$H$-кислоты в изо- и антеизокислоты и способствуют другим конверсиям [8]. Во многих горючих сланцах, каменных углях и других осадочных отложениях присутствуют н-парафины $\mathrm{C}_{18}-\mathrm{C}_{30}$ с $\mathrm{KH} \simeq 1$, имеющие концентрационный максимум при $\mathrm{C}_{20}-\mathrm{C}_{25}$. Высказано мнение, что эти парафины имеют бактериальное происхождение []. В молодых седиментах с возрастанием глубины их залегания (увеличением возраста) наблюдается уменьшение концентрации ненасыщенных кислот, их насыщение возможно под действием некоторых бактерий $\left[{ }^{10}\right]$.

Общеизвестно, что бактерии используют в качестве питательного субстрата также н-алканы. В геологических условиях составляющие геолипидов по их сопротивлению бактериальному воздействию можно представить в виде следующего ряда: $н$-алканы $<$ метилалканы $<$ ациклические изопреноиды $<$ нафтены $<$ ароматические соединения $<$ полярные соединения [1']. Бактерии расходуют преимущественно менее конденсированные и алкилированные системы. При исследовании воздействия микроорганизмов на горючие сланцы в последних идентифицирован ряд энзимов $\left[{ }^{12}\right]$.

Наши исследования по почвенным липидам $\left[{ }^{13}\right]$ показали, что в них присутствуют $H$-парафины $\mathrm{C}_{10}-\mathrm{C}_{33}$ с концентрационными максимумами у $\mathrm{C}_{15}$ и $\mathrm{C}_{24}$. Основную группу составляют $\mathrm{C}_{19}-\mathrm{C}_{26}$, у которых $\mathrm{KH} \geqslant 1 ;$ они имеют бактериальное происхождение. Состав парафинов изменяется в течение вегетационного периода: осенью после прекращения фотосинтетических процессов установлены в большом количестве только бактериальные парафины $\mathrm{C}_{19}-\mathrm{C}_{26}\left[{ }^{14}\right]$. Карбоновые кислоты (преимущественно жирные) составляют $27-37 \%$ от почвенных липидов, их главные представители $\mathrm{C}_{16}$ и $\mathrm{C}_{18}$. Генетическая связь между парафинами и кислотами не установлена.

В большинстве исследованных нами геолипидов (битумоидов), выделенных из горючих сланцев, каменных углей и других осадочных пород, присутствуют такие же парафины и кислоты, как и в почвенных липидах. $\boldsymbol{H}$-Парафины $\mathrm{C}_{18}-\mathrm{C}_{26}$, имеющие $\mathrm{KH} \simeq 1$, были обнаружены в оленекских, усть-каменогорских, эстонских кукерситовых и диктионемовых и многих других сланцах. В основном в горючих сланцах присутствуют кислоты $\mathrm{C}_{16}$ и $\mathrm{C}_{18}$, КЧ у которых по сравнению с КЧ у первичной биологической продукции невысокий. Сопутствующие керогены являются, как правило, сингенетичными, но характерные для них структурные элементы обычно отличаются от таковых в битумоидах.

Органическое вещество в геосфере в основном сосредоточено в виде керогена. Длина $\boldsymbol{н}$-углеродных цепей керогена соответствует степени биологической эволюции соответствующего геологического периода: в древних керогенах их длина не превышает $\mathrm{C}_{17}$, позже они удлиняются до $\mathrm{C}_{31}$. У части керогенов углеродные цепи имеют $\mathrm{KH}>1$, что указывает на их происхождение из первичной биологической продукции, но большинство керогенов имеет $\mathrm{KH} \simeq 1$. В настоящее время длина углеродных цепей в керогене определяется деструктивными методами, селективность которых невысокая, поэтому значения КН получаются заниженными; в керогене КН обязательно выше экспериментально определенных его значений. По имеющимся данным, в настоящее время трудно определить, является ли выравнивание длин углеродных цепей (понижение $\mathrm{KH}$ ) при фоссилизации результатом бактериальных или геохимических процессов.

В Приволжье, Средней Азии, Марокко и на Ближнем Востоке находятся большие запасы сернистых горючих сланцев, содержащих до $12 \%$ серы. Исходный биологический материал содержит мало серы, она включается в структуру осадочного вещества в ходе процессов седимен- 
тации и литогенеза. Сульфатредуцирующие бактерии расходуют в процессе своей жизнедеятельности в первую очередь $н$-углеводородные структуры органического вещества, вследствие чего в сернистых сланцах наблюдается повышенное содержание изопреновых углеводородов, имеющих разветвленную углеродную цепь и пониженное содержание водорода. Углеродные цепи керогена сернистых сланцев всегда имеют $\mathrm{KH} \simeq 1$. Процесс восстановления сульфатов в отношении органического вещества осадочной породы является окислительной реакцией. Главными представителями ациклических изопреновых углеводородов в осадочных породах являются фитан $\left(i \mathrm{C}_{20}\right)$ и пристан $\left(i \mathrm{C}_{19}\right)$. Если осадочная порода образуется в восстановительных условиях, как это имеет место в преобладающем количестве горючих сланцев, то $i \mathrm{C}_{20}>i \mathrm{C}_{19}$. В случае бурых и каменных углей, которые образуются в окислительной обстановке, $i \mathrm{C}_{19}>i \mathrm{C}_{20}$. В большинстве сернистых сланцев $i \mathrm{C}_{19}>i \mathrm{C}_{20}$, что согласуется с окислительной обстановкой литогенеза. Правда, при этом имеются также исключения - в некоторых сланцах Средней Азии (месторождения Памук, Чандыр и Уртабулак) наблюдается высокое содержание изопреновых углеводородов, но отношение $i \mathrm{C}_{19}: i \mathrm{C}_{20}$ составляет $0,5-0,7$, в битумоиде присутствуют $H$-парафины $\mathrm{C}_{13}-\mathrm{C}_{19}$, имеющие высокий КН [15]. В этом отношении сланцы Западного Узбекистана отличаются от других сернистых сланцев. В сернистых сланцах отмечается повышенное содержание кислорода, что может быть обусловлено присутствием в сланцах сульфатов - в процессе своей жизнедеятельности сульфатредуцирующие бактерии окисляют органическое вещество.

Эстонские диктионемовые сланцы и кукерсит имеют близкий возраст и залегают на одном и том же месте. В условиях раннего палеозоя материал их образования мог быть только один - синезеленые водоросли. Они никогда не опускались на большие глубины и поэтому геотермическому воздействию не подвергались. Несмотря на близкие условия образования, химический состав этих сланцев отличается коренным образом (см. таблицу). В кукерсите хорошо сохранились «нечетные»

Сравнительная характеристика эстонских диктионемовых сланцев и кукерсита

\begin{tabular}{|c|c|c|}
\hline Показатели & $\begin{array}{c}\text { Диктионемовый } \\
\text { сланец }\end{array}$ & Кукерсит \\
\hline $\begin{array}{l}\text { Возраст, млн. лет } \\
\text { Содержание органического вещества, \% } \\
\text { Показатели органического вещества: } \\
\text { содержание серы, \% } \\
\text { содержание битумоида, \% } \\
\text { содержание изопреновых структур } \\
\text { атомарное отношение Н/C } \\
\text { выход смолы полукоксования, \% } \\
\text { характер углеводородной части смолы } \\
\text { Минеральное вещество } \\
\text { Содержание биофильных элементов }\end{array}$ & $\begin{array}{c}470 \\
15-20 \\
2-4 \\
2-3,5 \\
\text { умеренное } \\
1,22 \\
8-15 \\
\text { ароматический } \\
\text { алюмосиликаты } \\
\text { высокое }\end{array}$ & $\begin{array}{c}450 \\
25-45 \\
1,0 \\
0,6 \\
\text { низкое } \\
1,48 \\
60-70 \\
\text { смешанный } \\
\text { карбонаты } \\
\text { низкое }\end{array}$ \\
\hline
\end{tabular}

углеродные цепи, кероген имеет в основном алифатическую структуру, пр:! полукоксовании образуется много смолы. В диктионемовых сланцах признаки первичной биологической продукции отсутствуют (кроме изопреновых углеводородов в битумоиде) и кероген имеет ароматическую структуру. Некоторое влияние на образование столь отличного фоссильного материала могло оказывать различие в составе минеральной части осадочной породы, но основные глубокоидущие процессы при 
образовании диктионемовых сланцев могли быть обусловлены только деятельностью бактерий.

Липтобиолитовые угли представляют собой малую, но характерную группу горючих ископаемых, которые образовались из восков и смол хвойных и саговых растений. н-Углеводороды и жирные кислоты в них имеют бактериальное происхождение, по составу они близки к почвенным липидам, но имеют более высокое содержание изопреновых структур. Липтобиолитовый уголь липовецкого месторождения Дальнего Востока является пока единственной осадочной породой, в которой присутствуют в большом количестве кислоты с изоструктурой, - возможно, это результат жизнедеятельности бактерий. В них чрезвычайно высока концентрация изопренового углеводорода $i \mathrm{C}_{19}$, что может быть обусловлено специфическим составом исходного биологического вещества, окислительной обстановкой седиментации и явлением концентрирования в результате израсходования других структур вещества бактериями. Несмотря на химическую стабильность сырья для формирования липтобиолитов, следов бактериальной деятельности в них больше, чем в осадочных породах, образующихся в восстановительных условиях.

Исследование состава органического вещества древних осадков показывает, что в ходе биологической эволюции бактерии опережали другие организмы; в то время как водоросли синтезировали кислоты до $\mathrm{C}_{18}$ (в небольшом количестве до $\mathrm{C}_{24}$ ), бактерии могли продуцировать кислоты и углеводороды с гораздо более длинной цепью.

По мнению большинства геохимиков, органический азот в осадочных отложениях имеет бактериальное происхождение (растения-углеобразователи содержат ничтожное количество азота). Некоторые сланцы - грин-риверские США и лотианские Шотландии - содержат $2-3 \%$ азота. Возможно, что действие бактерий сказалось также на липидных компонентах, но этот вопрос пока не изучен.

В настоящее время состав липидов у микроорганизмов изучается интенсивно [16]. Менее исследованы биосинтез и метаболизм бактериальных липидов в процессах фоссилизации, так как эти процессы протекают медленно. Вероятно, в будущем новые данные по образованию органического вещества будут получены в результате исследования осадков морей и континентальных водоемов, а также других современных осадков.

\section{ЛИТЕРАТУ РА}

1. Т а усон В. О. Наследство микробов. М., 1947.

2. Т а усон В. О. Основные положення растительной биоэнергетики. М., 1950.

3. Mo re, L. G. Geomicrobiology and geomicrobiological attack on sedimented organic matter. - In: Organic geochemistry. Berlin, 1969, p. 265-303.

4. У эта Н. Биохимия жирных кислот с разветвленной цепью. - Юкагаку, 1971, т. 20, № 10, с. 663-669. Перевод № 6458, ВЦП, 1973.

5. Дедюхина Э. Г., Андреев Л. В., Попков Г. П., Еротин В. К. Биосинтез углеводородов алканоокисляющими микроорганизмами. Микробиология, 1972 , т. 41 , № 4 , с. $664-667$.

6. Cranwe11, P. A. Organic geochemistry of lake sediments. - In: Environmental Biochemistry, v. 1. 1976, p. $75-88$.

7. Co m b a z, A. La matière algaire et l'origine du petrole. - Communication présentée au 6ème Congrès International de Géochimie Organique, Paris, 18-21 Septembre 1973.

8. L e o, R. F., Parker, P. L. Branched chain fatty ac:ds in the sediments. - Science, 1966 , v. 152 , p. $649-650$.

9. Вески Р. Э., Бондарь Е. Б., Фомина А. С. Об участин микробного материала в структуре керогена кукерсита. - Тез. докл. семинара Органическое вещество в современных и ископаемых осадках». М., 1976, с. 185-186. 
10. Rubinstein, I., Strausz, O. P., Spyckerelle, C., Cranford, R. J., We $\mathrm{t}$ l a ke, D. W. S. The origin of the oil sand bitumens of Alberta: a chemical and microbiological study. - Geochim. Cosmochim. Acta, 1977, v. 41, p. $1341-1351$.

11. Schonbrunner, J. Ober die bakterielle Hydrierung von Olsäure und Sorbinsäure und ihre Beeinflussung durch Gallensäure. - Biochem. Z., 1940, v. 304. S. $26-36$.

12. Yen, T. F. Microbial Oil Shale Extraction. - In: Microbial Energy Conversion, Pergamon Press, 1977, p. 309-328.

13. Клесмент И., Л илле п Н. К геохимии почвенных углеводородов Северной Эстонии. - Изв. АН ЭССР. Хим., 1978, т. 27, № 1, с. 8-14.

14. Клесмент И., Лиллеп Н., Урмет Э. Геохимия почвенных липоидов с точки зрения химиков. - Изв. АН ЭССР. Хим., 1978, т. 27, № 4, с. $260-267$.

15. У ров К. Э., А в а з м а тов Х. Б., Л и с т ем А. И. Геохимические особенности нижнеэоценовых горючих сланцев Западного Узбекистана. - В кн.: Накопление и преобразование органического вещества современных и ископаемых осадков. М., 1978, с. $133-140$.

16. Биосинтез и метаболизм липидов у микроорганизмов. Тез. докл. II Всесоюзной конференцин. М., 1979.
Ннститут химии
Академии наук Эстонской ССР
Поступила в редакцию 23/I 1980

\section{KLESMENT, K. UROV}

\section{BAKTERIAALSETE LIPIIDIDE OSA GEOLIPIIDIDE JA KEROGEENIDE MOODUSTUMISEL}

Fossiilistumisprotsessides tarbivad bakterid surnud orgaanilise aine valke ja süsivesinikke ning sünteesivad lipiide, mille koostis erineb primaarse bioloogilise aine lipiidide koostisest. Artiklis on esitatud Eesti kukersiit- ja diktüoneemapõlevkivi võrdlus; viimastes ilmneb tugev bakterite tegevuse mõju.

\section{KLESMENT, K. UROV}

\section{ROLE OF BACTERIAL LIPIDS IN THE FORMATION OF GEOLIPIDS AND KEROGENS}

During the fossilization process bacteria consume proteins and carbohydrates, and synthesize lipids that have a different composition from that of the primary biological matter. A comparison of Estonian kukersite and dictyonema oil shales is presented, a strong effect of bacterial activity having been stated in the latter. 